\title{
AKTIVITAS ANTIBAKTERI INFUSA DAUN LIDAH BUAYA (Aloe vera L) TERHADAP PERTUMBUHAN Staphylococcus aureus dan Escherichia coli
}

\author{
Yuni Widyastuti, Nia Yuliani*, I Gusti Ayu Manik W \\ Program Studi Biologi FMIPA Universitas Nusa Bangsa Bogor \\ Jl. KH. Sholeh Iskandar KM 4 Cimanggu Tanah Sareal Bogor 16166 \\ *email : niayuliani0412@gmail.com
}

\author{
ABSTRACT \\ Antibacterial Activity of Infused Aloe Vera Leaf (Aloe Vera L) on Growth Of Stapylococcus \\ aureus and Escherichia coli
}

\begin{abstract}
Disinfectants may act as antibacterials. Aloe vera (Aloe vera $L$ ) is one of the plants that is often used by the community as a medicinal plant that has many active compounds such as lignin, saponin and anthraquinone substances that act as antibacterial. This study aims to determine the antibacterial activity of Aloe vera leaf extracted with infusa method on the growth of Staphylococcus aureus and Escherichia coli bacteria. The research method is to see the reduction / reduction of bacterial count (\% reduction) after 30 second and 60 second with disc diffusion method. The results showed decrease or decrease of bacteria count (\% reduction) to Escherichia coli bacteria found in aloe leaf skin infected by $28,2 \%$ after 60 seconds. While decrease or decrease of bacteria amount (\% reduction) to Staphyloccocus uareus bacteria infusa mixture of meat and skin of Aloe vera leaves of $27.5 \%$ after 60 seconds. Antibacterial test of aloe vera leaf aloe (Aloe veraL) of 100\% concentration by disc diffusion method did not show any inhibition zone around cultures of test bacteria.
\end{abstract}

Keywords: Aloe vera, antibacterial activity, Staphylococcus aureus, and Escherichia coli, Infusa.

\begin{abstract}
ABSTRAK
Desinfektan dapat berfungsi sebagai antibakteri. Lidah buaya (Aloe vera L) merupakan salah satu tanaman yang sering digunakan masyarakat sebagai tanaman obat yang memiliki banyak senyawa aktif seperti lignin, saponin dan antrakuinon yaitu zat yang berfungsi sebagai antibakteri. Penelitian ini bertujuan untuk mengetahui aktivitas antibakteri daun lidah buaya (Aloe vera $\mathrm{L}$ ) yang diekstrak dengan metode infusa terhadap pertumbuhan bakteri Staphylococcus aureus dan Escherichia coli. Metode penelitian yaitu dengan melihat penurunan/pengurangan jumlah bakteri (\% reduksi) setelah waktu 30 detik dan 60 detik dengan metode difusi cakram. Hasil penelitian menunjukkan penurunan atau pengurangan jumlah bakteri (\% reduksi) terhadap bakteri Escherichia coli terdapat pada infusa kulit daun lidah buaya yaitu sebesar $28,2 \%$ setelah waktu 60 detik.Sedangkan penurunan atau pengurangan jumlah bakteri (\% reduksi) terhadap bakteri Staphyloccocus uareus terdapat pada infusa campuran daging dan kulit daun lidah buaya yaitu sebesar 27,5\% setelah waktu 60 detik. Uji antibakteri infusa daun lidah buaya (Aloe veraL) konsentrasi $100 \%$ dengan metode difusi cakram tidak menunjukkan adanya zona penghambatan disekitar biakan bakteri uji.
\end{abstract}

Kata kunci : Lidah buaya, Aktivitas antibakteri, Staphylococcus aureus, dan Escherichia coli, Infusa.

\section{PENDAHULUAN}

Bakteri merupakan mahluk hidup mikroskopik yang memiliki peran besar dalam kehidupan di bumi. Bakteri dapat ditemukan dihampir semua tempat ; di tanah, air, udara, dalam simbiosis dengan organisme lainnya maupun sebagai parasit (penyebab penyakit), bahkan dalam tubuh manusia. Beberapa kelompok bakteri dikenal sebagai agen penyebab infeksi dan penyakit, sedangkan kelompok lainnya dapat memberikan manfaat dibidang pangan, pengobatan dan industri (Pelczar, 1986).

Bakteri yang ada di sekitar kita dapat menyebabkan penyakit tetapi ada pula yang sangat penting bagi kehidupan manusia seperti bakteri Escherichia coli dan Staphylococcus aureus yang merupakan bakteri flora normal (mikrofloranormal) pada manusia. Bakteri 
Staphylococcus aureus merupakan bakteri floranormal pada kulit dan selaput lendir manusia. Staphylococcus aureus dapat menjadi penyebab infeksi kerusakan pada kulit atau luka pada organ tubuh jika bakteri ini mengalahkan pertahanan tubuh (immunitas). Saat bakteri masuk ke peredaran darah bakteri dapat menyebar ke organ lain dan menyebabkan infeksi (Anwar,2009 dalam Melki $d k k ., 2011$ ).

Escherichia coli adalah kuman yang ditemukan di usus besar manusia sebagai floranormal. Bakteri ini dapat menyebabkan infeksi primer pada usus misalnya diare pada anak. Di dalam usus kuman ini tidak menyebabkan penyakit, tetapi dapat membantu fungsi normal dan nutrisi. Bakteri Escherichia coli menjadi patogen hanya bila mencapai jaringan di luar saluran pencernaan khususnya saluran air kemih, saluran empedu, paru - paru, peritonium, atau selaput otak, menyebabkan peradangan pada tempat - tempat tersebu (Jawetz, 1986).

Keberadaan bakteri yang hidup di bagian tubuh tertentu pada manusia mempunyai peran penting dalam mempertahankan kesehatan dan hidup secara normal.Tetapi bakteri tersebut juga dapat menimbulkan penyakit pada kondisi tertentu. Bakteri ini tidak bisa tembus (non invasive) dengan adanya hambatanhambatan yang diperankan oleh lingkungan. Jika hambatan dari lingkungan dihilangkan dan bakteri masuk ke dalam jaringan atau aliran darah, bakteri ini mungkin menjadi patogen. Salah satu cara penghambatan terhadap bakteri ini adalah dengan penggunaan desinfektan yang berfungsi sebagai antibakteri (Jawetz,1986).

Antibakteri merupakan zat yang dapat menghambat pertumbuhan bakteri dan digunakan untuk mengobati infeksi. Antibakteri terdiri dari senyawa-senyawa aktif baik kimia sintetik atau produk alami yang dapat menghambat pertumbuhan bakteri. Salah satu tumbuhan yang sering digunakan masyarakat sebagai tanaman obat adalah tanaman lidah buaya (Aloe vera L). Lidah buaya mempunyai kandungan zat gizi yang diperlukan tubuh dengan cukup lengkap, yaitu vitamin A, B, C, E, choline, inositol dan asam folat. Kandungan mineralnya antara lain terdiri dari : kalsium $(\mathrm{Ca})$, magnesium $(\mathrm{Mg})$, potasium, sodium, besi $(\mathrm{Fe})$, zinc $(\mathrm{Zn})$, dan cromium $(\mathrm{Cr})$. Beberapa unsur vitamin dan mineral tersebut dapat berfungsi sebagai pembentuk antioksidan alami, seperti vitamin A, vitamin $\mathrm{C}$, vitamin $\mathrm{E}$, magnesium, dan zinc. Daun lidah buaya segar mengandung enzim amilase, selulosa, carboxypeptidase dan lain-lain. Selain itu lidah buaya juga mengandung sejumlah asam amino arginin, asparagin, asam aspartat, alanin, serin, valin, glutamate, treonin, glisin, lisin, prolin, hisudin, leusin dan isoleusin. Daging daun lidah buaya juga memiliki banyak senyawa aktif seperti lignin, antrakuinon (yaitu zat yang berfungsi sebagai antibakteri) dan saponin (Jamal, 2015).

Berdasarkan latar belakang diatas maka perlu dilakukan penelitian yang bertujuan untuk menguji aktivitas antibakteri daun lidah buaya yang diekstrak dengan cara infundasi dalam mempengaruhi pertumbuhan bakteri Escherichia coli dan bakteri Staphylococcus aureus.

\section{BAHAN DAN METODE}

\section{Bahan dan Alat}

Bahan yang digunakan dalam penelitian ini adalah daun lidah buaya (Aloe vera) berasal dari kebun lidah buaya Atang Sandjaja (ATS) Bogor, bakteri Escherichia coli ATCC 8739 dan bakteri Staphylococcus aureusATCC 6538 yang diperoleh dari Biofarma, $\mathrm{NaCl}$ fisiologis 0,85\%, Trypticase Soy Agar, Trypticase Soy Broth, Nutrient Agar dan aquadest.

Alat yang digunakan adalah tabung reaksi, gelas ukur, cawan petri, batang pengaduk, alat ukur berat, water bath, inkubator, pengukur waktu, pisau, sendok, corong pisah, mikropipet, autoclave, kertas saring, alat pencacah.

\section{Metode}

\section{Determinasi Tanaman}

Determinasi dilakukan untuk memastikan kebenaran bahan yang akan digunakan dalam penelitian. Determinasi dilakukan di Pusat Penelitian Biologi - 
Lembaga Ilmu Pengetahuan Indonesia (LIPI) di Cibinong, Bogor.

\section{Teknik Pengambilan Sampel Lidah Buaya}

Sampel daging daun lidah buaya yang digunakan diperoleh dari kebun lidah buaya Atang Sendjaja (ATS) Bogor. Daun lidah buaya yang digunakan adalah yang tua yaitu daun yang terletak paling bawah (daun 1 dan 2) yang diambil dari beberapa tanaman lidah buaya secara acak pada satu petak kebun lidah buaya dengan umur tanaman yang sama.

\section{Infusa Lidah buaya}

Lidah buaya dicuci, dikupas untuk diambil daging daunnya, kemudian ditimbang sebanyak 100 gram dan diletakkan dalam gelas ukur ukuran 1500 ml. Ditambahkan air sebanyak $1000 \mathrm{ml}$ dan diletakkan ke dalam water bath dengan suhu $95^{\circ} \mathrm{C}$ selama 15 menit. Setelah itu, campuran yang masih panas disaring ke dalam gelas ukur dengan menggunakan corong kaca yang telah dilapisi kain kassa dan kertas saring. Cairan infus hasil penyaringan diuapkan dalam water bath dengan suhu $95^{\circ} \mathrm{C}$ selama 120 menit sambil diaduk sesekali, sehingga cairan infus susut dari $1000 \mathrm{cc}$ menjadi $100 \mathrm{cc}$ dan diperoleh konsentrasi infusum lidah buaya 100\% (Iriano,2008).

\section{Pembuatan Larutan Bakteri Uji (Dahlan \& Arief F, 1990)}

Trypticase Soy Broth disiapkan dalam tabung reaksi sebanyak $10 \mathrm{~mL}$. Biakan murni bakteri uji pada agar miring NA diinokulasikan ke dalam media Trypticase Soy Broth dengan cara memipet satu $\mathrm{ml}$ Trypticase Soy Broth kemudian dimasukkan ke dalam biakan murni bakteri uji pada agar miring NA. Bakteri yang ada pada permukaan agar miring diemulsikan dengan menggunakan pipet atau ose sampai tidak ada lagi bakteri yang tertinggal pada permukaan agar miring. Trypticase Soy Broth yang terdapat pada tabung agar miring dimasukkan kembali ke dalam tabung reaksi yang berisi Trypticase Soy Broth dan prosedur ini di ulangi sampai benar-benar tidak ada lagi mikroba yang tertinggal. Tabung yang telah berisi $10 \mathrm{ml}$ Trypticase Soy Broth dan bakteri tersebut kemudian diinkubasikan pada suhu $37^{\circ} \mathrm{C}$ selama 24 jam. Kemudian dibuat seri pengenceran dengan $\mathrm{NaCl}$ fisiologis sampai pengenceran $10^{-11}$ atau tergantung dengan populasi bakteri yang diduga. Sebanyak satu $\mathrm{mL}$ suspensi pada masing-masing pengenceran dipipet ke dalam cawan petri yang berisi media Trypticase Soy Agar. Cawan petri berisi media agar dan suspensi bakteri tersebut diinkubasi pada suhu $37^{\circ} \mathrm{C}$ selama 24 jam. Koloni yang tumbuh dihitung dan dicatat dalam satuan koloni/mL. Berdasarkan nilai koloni $/ \mathrm{mL}$ hasil perhitungan, diperoleh jumlah bakteri sebagai berikut :

$$
\begin{aligned}
& \text { Staphyloccocus aureus }=8,0 \times 10^{7} \\
& \text { koloni } / \mathrm{ml} \\
& \begin{array}{l}
\text { Escherichia coli }=9,9 \times 10^{6} \\
\text { koloni } / \mathrm{ml} \text {. }
\end{array}
\end{aligned}
$$

\section{Uji Antibakteri (menurut AOAC, 2000)}

Uji yang digunakan adalah menentukan adanya pengurangan atau penurunan jumlah bakteri setelah bakteri uji hasil perhitungan yang diperoleh di campur dengan infusa daun lidah buaya selama 30 detik dan 60 detik. Konsentrasi infusa lidah buaya disiapkan dalam tabung reaksi sebanyak $100 \mathrm{ml}$. Sebanyak satu ml larutan bakteri uji hasil perhitungan dimasukkan ke dalam tabung reaksi yang berisi $100 \mathrm{ml}$ infusa lidah buaya.Campur perlahan agar homogen, dari campuran tersebut dibuat pengenceran dari $10^{-1}$ sampai $10^{-6}$ dengan cara mengambil $1 \mathrm{ml}$ campuran (ekstrak + bakteri) ditambah $9 \mathrm{ml} \mathrm{NaCl}$ fisiologis (= pengenceran $10^{-1}$ ), dari pengenceran $10^{-1}$ diambil $1 \mathrm{ml}$ ditambah $9 \mathrm{ml} \mathrm{NaCl}$ fisiologis (= pengenceran $\left.10^{-2}\right)$. Begitu selanjutnya sampai diperoleh pengenceran $10^{-6}$. Nyalakan pengukur waktu, setelah 30 detik, ambil $1 \mathrm{ml}$ dari setiap pengenceran tadi kemudian diinokulasikan pada cawan petri yang berisi Trypticase Soy Agar. Setelah 60 detik kemudian ambil lagi $1 \mathrm{ml}$ dan di inokulasi pada cawan petri yang berisi Trypticase Soy Agar. Diinkubasi pada suhu $37^{\circ} \mathrm{C}$ selama 24 jam dalam inkubator. Dilihat ada tidaknya pertumbuhan koloni 
pada setiap masing-masing pengenceran. Koloni yang tumbuh dicatat dan di hitung, hasil perhitungan dinyatakan dalam persen. Adanya penurunan atau pengurangan jumlah bakteri menandakan adanya pengaruh antibakteri daging daun lidah buaya terhadap pertumbuhan bakteri uji.

\section{Uji Antibakteri Metode Difusi Cakram (SNI,2008) \\ Satu ml larutan bakteri uji} diinokulasikan ke dalam tabung yang berisi $100 \mathrm{ml}$ Nutrient Agar yang bersuhu $\pm 45^{\circ}$ C. Campurkan perlahan - lahan sampai homogen, kemudian dituangkan ke dalam cawan petri sebanyak $15 \mathrm{ml}$. Biarkan Nutrient Agar yang telah mengandung bakteri uji tersebut membeku. Setelah membeku diletakkan kertas cakram berdiameter $8 \mathrm{~mm}$ yang telah ditetesi infusa daging daun lidah buaya sebanyak $75 \mu 1$ di tengah-tengah cawan petri. Teteskan juga pada kertas cakram antibiotik kloramfenikol $125 \mathrm{mg} / \mathrm{ml}$ sebagai kontrol positif dan aquadest steril sebagai kontrol negatif. Simpan cawan petri dalam inkubator pada suhu $37^{\circ} \mathrm{C}$ selama 24 jam. Aktifitas antibakteri dapat dilihat dengan terbentuknya zona hambat berupa daerah bening di sekitar kertas cakram pada cawan petri.

\section{HASIL DAN PEMBAHASAN}

\section{Determinasi Tanaman}

Tanaman Lidah buaya hasil determinasi yang dilakukan di Pusat Penelitian Biologi LIPI cibinong Bogor, yang digunakan dalam penelitian ini adalah tanaman Lidah buaya jenis Aloe vera $(\mathrm{L})$ Burn.f. Daun yang digunakan adalah daun lidah buaya yang berdaging tebal dengan berat pelepah antara 0,5 - I kg, berwarna hijau keabu-abuan dan mempunyai lapisan lilin di permukaannya.

\section{Infusa Lidah Buaya (Aloe vera $\mathrm{L}$ )}

Hasil infusa lidah buaya (Aloe vera L) dari masing - masing bagian daun lidah buaya menimbulkan warna - warna yang berbeda. Infusa daging daun berwarna merah muda, infusa kulit daun berwarna hijau kekuningan , infusa campuran daging dan kulit daun memberikan warna merah jingga. Perubahan warna yang terjadi pada infusa dimungkinkan disebabkan adanya pemanasan yang lama pada saat pembuatan infusa dan adanya sifat air yang dapat melarutkan zat warna pada tumbuhan atau juga karena terjadi oksidasi dan adanya pengaruh langsung sinar matahari. Gel atau daging lidah buaya bersifat koloidal seperti lendir, terutama jika pHnya mendekati basa (saat masih segar) bentuknya berupa gel sangat lekat, tetapi jika pHnya mendekati asam (saat daun layu) akan berubah wujud menjadi sol yang bersifat lebih encer seperti sirup. Penurunan kekentalan daging daun lidah buaya disebabkan karena adanya hidrolisa polisakarida oleh enzim yang masih mempunyai aktivitas tinggi dan diikuti oleh perubahan warna menjadi gelap. Daging (gel) lidah buaya memiliki sifat sangat mudah teroksidasi karena mengandung enzim oksidase sehingga gel akan berubah warna menjadi kuning hingga coklat. Kandungan asam organik dalam gel lidah buaya berubah - ubah tergantung kondisi penyimpanan daun lidah buaya. Adanya kuinon dan antrakuinon dalam daging lidah buaya dengan adanya cahaya akan menyebabkan perubahan warna menjadi kemerah-merahan dan akhirnya membentuk warna coklat. Perubahan warna ini dapat terjadi secara enzimatis dan non enzimatis. Pada daging daun lidah buaya proses oksidasi dengan adanya oksigen dapat juga menyebabkan terbentuknya aloin $\left(\mathrm{C}_{22} \mathrm{H}_{22} \mathrm{O}_{9}\right)$ yang dikenal sebagai bahan kontaminator (Adha P.W, 2011). Ini merupakan hal yang tidak diharapkan dalam suatu pemeriksaan karena dapat menjadi bahan pengganggu.

\section{Uji Antibakteri}

Penurunan atau pengurangan jumlah bakteri (\% reduksi) terhadap Staphylococcus aureus terlihat bahwa aktivitas antibakteri lebih banyak terdapat pada infusa campuran daging dan kulit daun lidah buaya dalam waktu 30 detik yaitu sebesar $17,5 \%$ dan dalam waktu 60 detik sebesar 27,5\%.

Penurunan atau pengurangan jumlah bakteri (\% reduksi) terhadap Escherichia coli dalam waktu 30 detik dan 60 detik 
dapat dilihat Tabel 1 dan 2 serta Gambar 1 dan 2. Aktivitas antibakteri infusa terhadap Escherichia coli lebih banyak terdapat pada infusa kulit daun lidah buaya yaitu sebesar $21,2 \%$ dan dalam waktu 60 detik sebesar $28,3 \%$

Tabel 1 .Hasil Uji Penurunan Bakteri (\% Reduksi) Waktu 30 Detik

\begin{tabular}{|c|c|c|c|c|c|c|c|c|c|}
\hline \multirow[b]{2}{*}{ Sampel } & \multirow[b]{2}{*}{ Bakteri Uji } & \multicolumn{6}{|c|}{ Hasil Uji } & \multirow[b]{2}{*}{$\begin{array}{l}\text { Total } \\
\text { Bakteri }\end{array}$} & \multirow{2}{*}{$\begin{array}{l}\% \\
\text { Reduks }\end{array}$} \\
\hline & & $\begin{array}{l}\text { Penge } \\
-2\end{array}$ & $\begin{array}{l}\text { ceran } \\
-3\end{array}$ & -4 & -5 & -6 & -7 & & \\
\hline \multirow{2}{*}{$\begin{array}{l}\text { Infusa } \\
\text { daging } \\
\text { daun }\end{array}$} & S. aureus & Tbud & Tbud & Tbud & Tbud & 79 & 10 & $7,9 \times 10^{7}$ & 1,2 \\
\hline & E. coli & Tbud & Tbud & Tbud & 87 & 7 & 0 & $8,7 \times 10^{6}$ & 12,1 \\
\hline \multirow{2}{*}{$\begin{array}{l}\text { Infusa } \\
\text { kulit daun }\end{array}$} & S. aureus & Tbud & Tbud & Tbud & Tbud & 76 & 13 & $7,6 \times 10^{7}$ & 5,0 \\
\hline & E. coli & Tbud & Tbud & Tbud & 78 & 15 & 3 & $7,8 \times 10^{6}$ & 21,2 \\
\hline \multirow{2}{*}{$\begin{array}{l}\text { Infusa } \\
\text { daging\& } \\
\text { kulit }\end{array}$} & S. aureus & Tbud & Tbud & Tbud & Tbud & 66 & 10 & $6,6 \times 10^{7}$ & 17,5 \\
\hline & E. coli & Tbud & Tbud & Tbud & 89 & 7 & 1 & $8,9 \times 10^{6}$ & 10,1 \\
\hline
\end{tabular}

Keterangan : Tbud $=$ Tidak bisa untuk dihitung

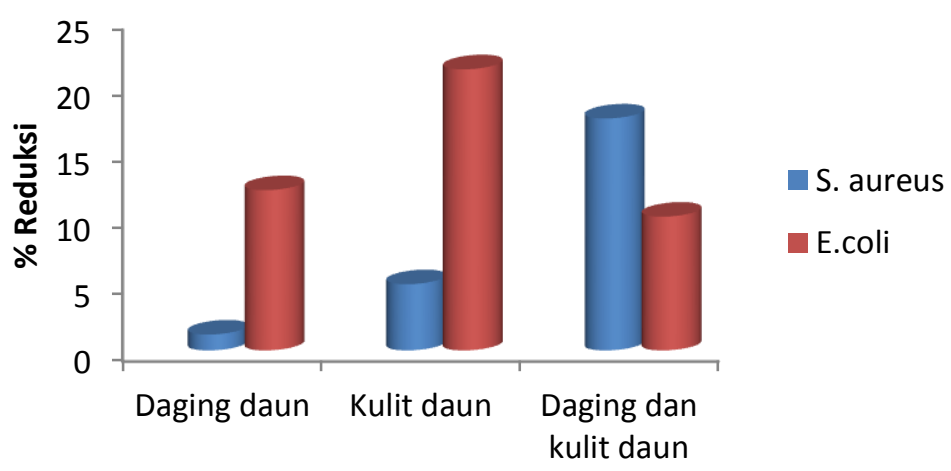

Gambar 1. \% Reduksi Jumlah Bakteri S. aureus dan E.coli dalam 30 detik pada infusa daun lidah buaya 
Tabel 2. Hasil Uji Penurunan Bakteri (\% Reduksi) Waktu 60 Detik

\begin{tabular}{|c|c|c|c|c|c|c|c|c|c|}
\hline \multirow{3}{*}{ Sampel } & \multirow{3}{*}{ Bakteri uji } & \multicolumn{6}{|c|}{ Hasil Uji } & \multirow{3}{*}{$\begin{array}{c}\text { Total } \\
\text { Bakteri }\end{array}$} & \multirow{3}{*}{$\begin{array}{c}\% \\
\text { Reduks }\end{array}$} \\
\hline & & & & engenc & $\operatorname{ran}$ & & & & \\
\hline & & -2 & -3 & -4 & -5 & -6 & -7 & & \\
\hline \multirow{2}{*}{$\begin{array}{r}\text { Infusa } \\
\text { daging daun }\end{array}$} & S. aureus & Tbud & Tbud & Tbud & Tbud & 67 & 7 & $\begin{array}{c}6,7 \times \\
10^{7}\end{array}$ & 16,2 \\
\hline & E. coli & Tbud & Tbud & Tbud & 75 & 11 & 2 & $\begin{array}{c}7,5 x \\
10^{6}\end{array}$ & 24,0 \\
\hline \multirow{2}{*}{$\begin{array}{r}\text { Infusa } \\
\text { kulit daun }\end{array}$} & S. aureus & Tbud & Tbud & Tbud & Tbud & 75 & 6 & $\begin{array}{c}7,5 \times \\
10^{7}\end{array}$ & 6,2 \\
\hline & E. coli & Tbud & Tbud & Tbud & 71 & 12 & 1 & $\begin{array}{c}7,1 \mathrm{x} \\
10^{6}\end{array}$ & 28,3 \\
\hline \multirow{2}{*}{$\begin{array}{r}\text { Infusa } \\
\text { daging\& } \\
\text { kulit }\end{array}$} & S. aureus & Tbud & Tbud & Tbud & Tbud & 58 & 9 & $\begin{array}{c}5,8 x \\
10^{7}\end{array}$ & 27,5 \\
\hline & E. coli & Tbud & Tbud & Tbud & 74 & 7 & 0 & $\begin{array}{c}7,4 \times \\
10^{6}\end{array}$ & 25,2 \\
\hline
\end{tabular}

Keterangan : Tbud $=$ Tidak bisa untuk dihitung

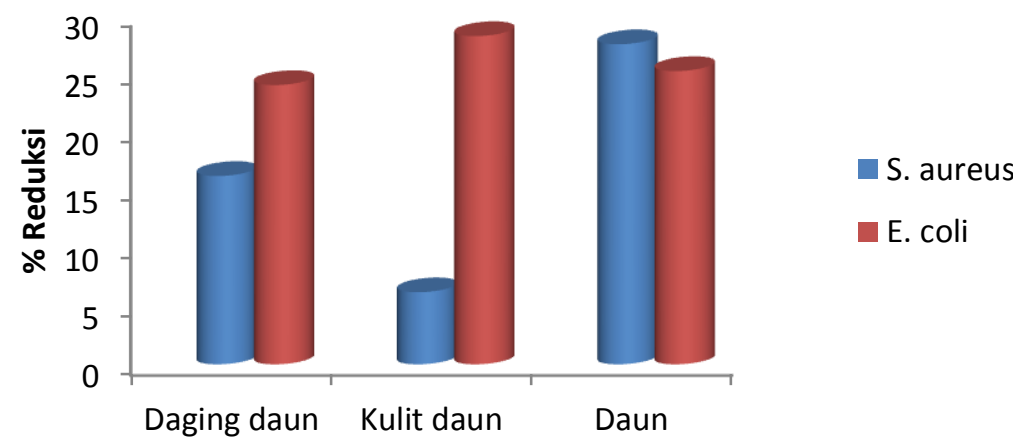

Gambar 2. \% Reduksi Jumlah Bakteri S. aureus dan E. coli dalam 60 detik pada infusa daun lidah buaya

Hasil penurunan jumlah bakteri (\% reduksi) terhadap bakteri Staphylococcus aureus diperoleh hasil bahwa pada pengujian dalam waktu 30 detik nilai terbesar terdapat pada sampel infusa campuran daging dan kulit daun lidah buaya yaitu sebesar $17,5 \%$ pada pengenceran $10^{-6}$ dan nilai terkecil terdapat pada infusa daging daun lidah buaya yaitu $1,2 \%$ pada pengenceran $10^{-6}$. Sedangkan dalam waktu 60 detik penurunan jumlah bakteri (\% reduksi) terbesar adalah pada infusa campuran daging dan kulit daun lidah buaya sebesar $27,5 \%$ pada pengenceran $10^{-6}$ dan nilai terkecil adalah infusa kulit daun lidah buaya sebesar $6,2 \%$ pada pengenceran $10^{-6}$. Hasil uji antibakteri pada Escherichia coli penurunan jumlah bakteri terbesar selama waktu 30 detik terjadi pada infusa kulit daun lidah buaya sebesar $21,2 \%$ pada pengenceran $10^{-5}$ dan terkecil pada infusa daun (campuran daging dan kulit) lidah 
buaya sebesar $10,1 \%$ pada pengencera $10^{-}$ 5. Sedangkan dalam waktu 60 detik penurunan jumlah bakteri Escherichia coli terdapat pada infusa kulit daun lidah buaya yaitu sebesar $28,3 \%$ pada pengenceran $10^{-5}$ dan yang terkecil pada infusa daging daun lidah buaya yaitu $24.0 \%$ pada pengenceran $10^{-5}$.

Secara umum berdasarkan hasil uji antibakteri daun lidah buaya menurut metode AOAC (tahun 2000) dengan melihat penurunan jumlah bakteri, infusa bagian dari daun lidah buaya yang mempunyai potensi antibakteri adalah terletak pada bagian kulit daun dan pada daun ( campuran kulit dan daging daun) lidah buaya. Lamanya waktu kontak antara bakteri uji dan ekstrak (infusa) lidah buaya pun mempengaruhi terjadinya penurunan jumlah bakteri. Semakin lama waktu kontak semakin besar nilai penurunan jumlah bakteri yang terjadi. Hal ini juga berkaitan dengan jumlah mikroorganisme yang mempengaruhi kerja antibakterinya, artinya semakin banyak jumlah mikroorganisme yang ada maka makin banyak pula waktu yang diperlukan untuk membunuhnya (Pelczar,1988). Menurut standar AOAC 2000 nilai yang paling baik suatu zat antibakteri yang dapat digunakan sebagai desinfektan adalah 99,9\%. Konsentrasi terendah dari suatu antibakteri yang dapat membunuh 99,9 \% bakteri disebut Konsentrasi Bakterisid Minimal (KBM) (Rachman, 2011). Dari hasil uji tersebut bila dibandingkan dengan nilai Konsentrasi Bakterisid Minimal (KBM) 99,9 \%, ekstrak lidah buaya dengan metode infundasi mempunyai daya antibakteri yang sangat kecil. Perbandingan nilai tersebut dapat dilihat pada Tabel 3 dan 4 .

Tabel 3. Perbandingan Konsentrasi Kandungan Zat Antibakteri Infusa Lidah Buaya Dengan Nilai KBM 99,9\% Terhadap Bakteri Uji Setelah 30 Detik

\begin{tabular}{lcc}
\hline $\begin{array}{c}\text { Sampel infusa lidah } \\
\text { buaya }\end{array}$ & Staphyloccocus aureus & Escherichia coli \\
\hline Daging daun & $1,2 \%: 99,9 \%=0,012 \%$ & $12,1 \%: 99,9 \%=0,12 \%$ \\
Kulit daun & $5 \%: 99,9 \%=0,05 \%$ & $21,2 \%: 99,9 \%=0,21 \%$ \\
$\begin{array}{l}\text { Daun(daging\&kulit } \\
\text { daun) }\end{array}$ & $17,5 \%: 99,9 \%=0,17 \%$ & $10,1 \%: 99,9 \%=0,10 \%$ \\
\hline
\end{tabular}

Tabel 4. Perbandingan Konsentrasi Kandungan Zat Antibakteri Infusa Lidah Buaya Dengan Nilai KBM 99,9 \% Terhadap Bakteri Uji Setelah 60 Detik

\begin{tabular}{lcc}
\hline $\begin{array}{c}\text { Sampel infusa } \\
\text { lidah buaya }\end{array}$ & Bakteri Staphyloccocus aureus & Bakteri Escherichia coli \\
\hline Daging daun & $16,2 \%: 99,9 \%=0,16 \%$ & $24 \%: 99,9 \%=0,24 \%$ \\
$\begin{array}{l}\text { Kulit daun } \\
\begin{array}{l}\text { Daun (daging\& } \\
\text { kulit daun) }\end{array}\end{array}$ & $6,2 \%: 99,9 \%=0,62 \%$ & $28,2 \%: 99,9 \%=0,28 \%$ \\
\hline
\end{tabular}


Potensi daya antibakteri ekstrak daun lidah buaya dengan metode infundasi didapatkan hasil dalam jumlah sangat kecil (sedikit) karena pembuatan ekstrak dengan cara infundasi ini menggunakan pelarut air sebagai penyari zat aktif. Menurut Farmakope Indonesia menetapkan bahwa sebagai penyari adalah air, etanol, etanol-air atau eter. Air dipertimbangkan sebagai penyari karena murah dan mudah diperoleh, stabil, alamiah, tidak beracun, tidak mudah menguap dan tidak mudah terbakar.Tetapi kerugian penggunaan air sebagai penyari adalah air tidak selektif dalam menarik zat aktif, sari yang diperoleh dapat ditumbuhi kapang dan kuman serta cepat rusak, dan untuk pengeringannya perlu waktu lama. Air disamping melarutkan garam alkaloid, minyak menguap, glikosida, tanin dan gula, juga melarutkan gom, pati, protein, lendir, enzim, lilin, lemak, pektin, zat warna dan asam organik. Sehingga penggunaan air sebagai cairan penyari kurang menguntungkan, disamping zat aktif ikut tersari juga zat lain yang tidak diperlukan atau malah mengganggu proses pembuatan sari seperti gom, pati, protein, lemak, enzim, lendir dan lain - lain (Depkes RI,1979). Terbentuknya kontaminator dalam infusa lidah buaya juga memungkinkan menjadi salah satu faktor berkurangnya daya antibakteri dari infusa daun lidah buaya.

\section{Uji Antibakteri Dengan Cara Difusi Cakram (SNI,2008)}

Hasil uji antibakteri dengan metode difusi cakram infusa lidah buaya dari setiap bagian daun lidah buaya yaitu infusa daging daun lidah buaya, infusa kulit daun lidah buaya dan infusa campuran kulit dan daging daun lidah buaya tidak menunjukkan adanya zona hambatan pada biakan bakteri Staphyloccocus aureus dan biakan bakteri Escherichia coli. Hasilnya tidak berbeda dengan kontrol negatif, sedangkan kontrol positif dengan antibiotik kloramfenikol $125 \mathrm{mg} / \mathrm{ml}$ menunjukkan zona rata - rata sebesar $32,27 \mathrm{~mm}$ pada biakan Staphyloccocus aureus dan zona rata - rata sebesar 29,21 mm pada bakteri
Escherichia coli. Hasil tersebut dapat dilihat pada Gambar 3, 4, 5.

Menurut penelitian Iriano (2008), hasil uji identifikasi fitokimia infusa lidah buaya ditemukan kandungan antrakuinon, tanin dan fenol. Antrakuinon dalam lidah buaya ternyata mampu berperan sebagai antibiotik yang bersifat bakteriostatik. Tanin dalam konsentrasi rendah mampu menghambat pertumbuhan bakteri, sedangkan pada konsentrasi tinggi mampu bertindak sebagai antibakteri dengan cara mengkoagulasi atau menggumpalkan protoplasma bakteri sehingga terbentuk ikatan yang stabil dengan protein bakteri (Amelia.L,2014). Uji antibakteri infusa lidah buaya terhadap bakteri Staphyloccocus aureus dan bakteri Escherichia coli tidak menunjukkan adanya penghambatan pertumbuhan inokulum, yang ditandainya dengan tidak adanya zona bening yang terbentuk. Hal ini dapat disebabkan oleh banyaknya faktor yang berpengaruh terhadap zona hambatan yang dihasilkan pada metode difusi antara lain kecepatan difusi, sifat media agar yang digunakan, jumlah organisme yang diinokulasi, kecepatan tumbuh bakteri, konsentrasi bahan kimia, serta kondisi pada saat inkubasi sehingga diperlukan adanya standarisasi keadaan untuk memperoleh hasil yang dapat dipercaya (Anonim,2001 dlm Ariyanti NK dkk,2012).

Adanya kelemahan penggunaan air sebagai cairan penyari dalam metode infundasi dapat menyebabkan zat aktif yang tertarik kemungkinan sebagian akan mengendap kembali apabila kelarutannya sudah mendingin (lewat jenuh), menyebabkan hilangnya zat - zat atsiri, dan adanya zat - zat yang tidak tahan panas lama, disamping itu simplisia yang mengandung zat albumin (protein), zat ini akan menggumpal dan menyulitkan penarikan zat - zat berkhasiat yang terdapat pada simplisia. Disamping itu adanya air akan mempercepat proses hidrolisa. Untuk memekatkan sari air dibutuhkan waktu dan bahan bakar lebih banyak biladibandingkan dengan etanol (Depkes RI,1979). 


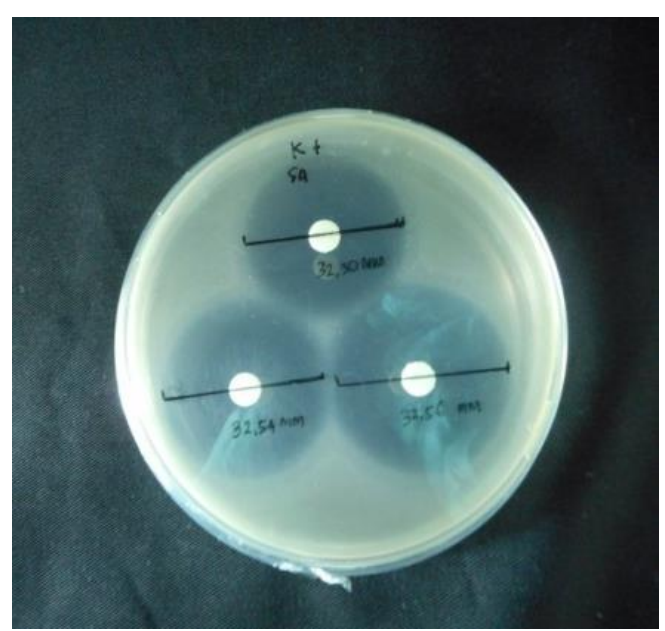

(a)

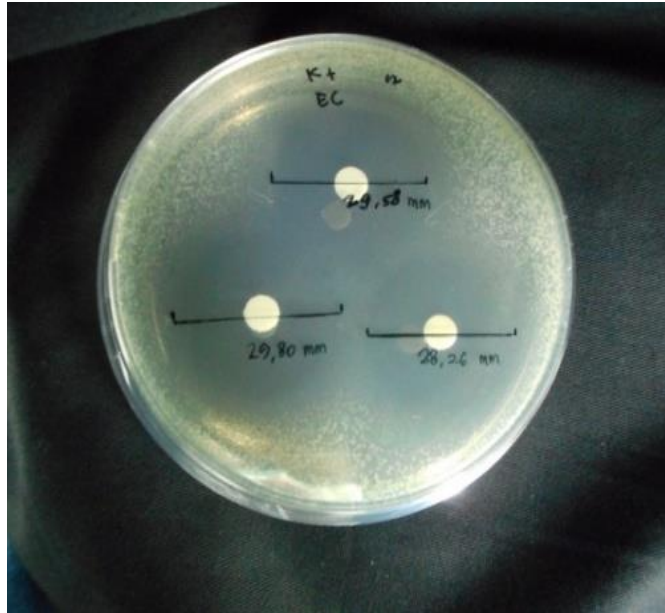

(b)

Gambar 3. Diameter zona hambat kloramfenikol terhadap (a) bakteri Staphyloccocus aureus (b) bakteri Escherichia coli

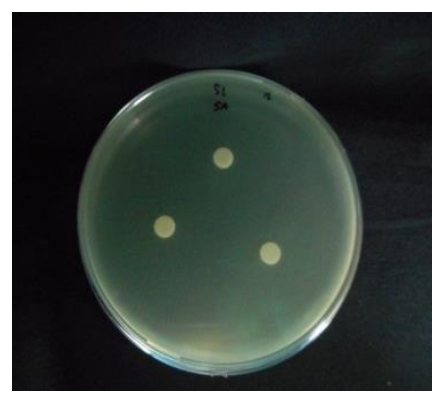

(a)

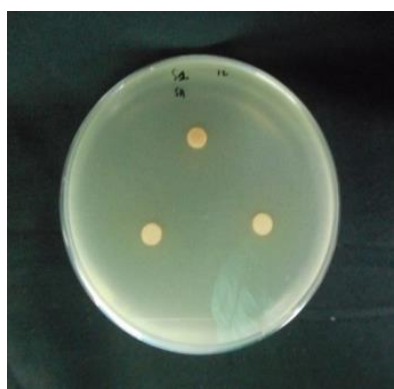

(b)

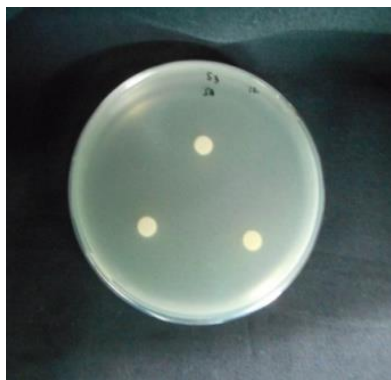

(c)

Gambar 4. Hasil zona hambat terhadap bakteri Staphyloccocus aureus (a) infusa daging daun lidah buaya (b)infusa kulit daun lidah buaya (c) infusa daging\&kulit daun lidah buaya

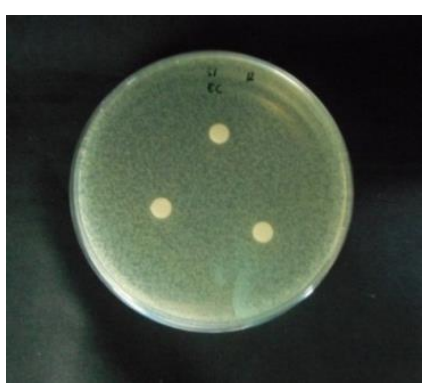

(a)

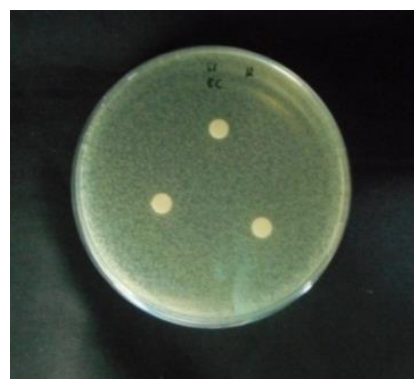

(b)

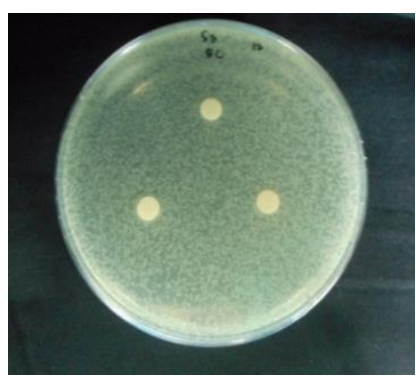

(c)

Gambar 5. Hasil zona hambat terhadap bakteri Escherichia coli (a) infusa daging daun lidah buaya (b) infusa kulit daun lidah buaya (c) infusa daging\&kulit daun lidah buaya 


\section{KESIMPULAN}

Aktivitas antibakteri lebih banyak terdapat pada bagian kulit dan daun (daging serta kulit daun) lidah buaya. Penurunan atau pengurangan jumlah bakteri (\% reduksi) terhadap bakteri Escherichia coli terdapat pada infusa kulit daun lidah buaya yaitu sebesar 28,2 \% setelah kontak atau tercampur selama 60 detik antara infusa dengan bakteri uji Escherichia coli. Penurunan atau pengurangan jumlah bakteri (\% reduksi) terhadap bakteri Staphyloccocus uareus terdapat pada infusa daun (daging \& kulit daun) lidah buaya yaitu sebesar $27,5 \%$ setelah kontak atau tercampur selama 60 detik antara infusa dengan bakteri uji Staphyloccocus aureus. Uji antibakteri infusa daun lidah buaya dengan metode difusi cakram tidak menunjukkan adanya zona penghambatan di sekitar biakan bakteri uji.

\section{DAFTAR PUSTAKA}

AOAC International Official Methods of Analysis. 2000. Germicidal and Detergent Sanitizing Action of Desinfectants. AOAC Official Method 960.09.Chapter 6.p.10.

Amelia Lisa. 2014. Uji Aktivitas Antibakteri Ekstrak Kulit Manggis (Garcinia mangostana L)TerhadapStaphylococcus aureus Dan Pseudomonas auruginosa (Skripsi S1).Fakultas Matematika dan Ilmu Pengetahuan Alam. Universitas Nusa Bangsa. Bogor.

Ariyanti,NK. I.B.G Darmayasa dan S.K Sudirga, 2012.Daya Hambat Kulit Daun Lidah Buaya (Aloe barbadensis Miller) Terhadap Pertumbuhan Bakteri Staphylococcus aureus ATCC 25923 Dan Eschericia coli ATCC 25922. Jurusan Biologi. Fakultas Matematika dan Ilmu Pengetahuan Alam. Universitas Udayana. Bukit Jimbaran.
Adha PW. 2009. Potensi Lidah Buaya Pontianak (Aloe Chinensis Lin) Sebagai Bahan Baku Industri Berbasis Sumber Daya Lokal. Program Teknologi Industri Pertanian Pasca Sarjana Teknologi Pertanian . Universitas Brawijaya. Malang

BSNI.2008. Metode Uji (Screening Test) Residu Antibiotik Pada Daging, Telur Dan Susu Secara Bioassay.SNI 7424.Badan Standarisasi Nasional. Jakarta.

Dahlan MA dan Arief Fuad, 1990, Penuntun Praktikum Mikrobiologi, Departemen Perindustrian, Akademi Analis Kimia, Bogor.

Departemen Kesehatan RI. 1979.

Farmakope Indonesia. Edisi III. Jakarta.

David W. 2000. Superfoods, The Food and Medicine of the Future. North Atlantic Books. Berkeley. California.

Febram B.P dan Vetnizah J, 2005, Aktivitas Sediaan Gel Dari Ekstrak Lidah Buaya (Aloe Baebadensis Miller) Untuk Proses Persembuhan Luka Pada Hewan, LPPM,IPB,Bogor.

Iriano, A. 2008. Efek Antibakteri Infusum Aloe vera terhadap Porphyromonas gingivalis In Vitro (perbandingan Metode Ekstraksi Maserasi dan Infundasi) (Skripsi S-1), Fakultas Kedokteran Gigi Program Studi Pendidikan Dokter Gigi, Universitas Indonesia. Jakarta.

Ika Lestari S. 2011. Potensi Antijamur Ekstrak Daun Sirih Merah dan Sirih Hijau Terhadap Pertumbuhan Jamur Candida albicans. Fakultas Matematika dan Ilmu Pengetahuan Alam. Universitas Nusa Bangsa. Bogor 
Jamal A. 2015. Intensif Budidaya Lidah Buaya Usaha Dengan Prospek yang Kian Berjaya. Cetakan 1. Pustaka Baru press. Yogyakarta.

Jawetz, E, G.E. Melnick, C.A. Adelberg. 1986. Mikrobiologi (Untuk Profesi Kesehatan). Edisi 16. Diterjemahkan oleh Tonang. EGC Penerbit Buku Kedokteran. Jakarta.

Jawetz, E., J.L. Melnick., Adelberg., G.F. Brooks., J.S. Butel., dan L.N.Ornston. 1996. Mikrobiologi Kedokteran. Edisi ke-20 (Alih bahasa :Nugroho\& R.F.Maulany). Penerbit Buku Kedokteran EGC. Jakarta.

Melki, W.A., E.P. Kurniati. 2011. Uji Antibakteri Ekstrak Gracilaria Sp (Rumput Laut) Terhadap Bakteri
E.coli dan S.aureus, Program Studi Ilmu Kelautan Fakultas Matematika dan Ilmu Pengethuan Alam. Universitas Indralaya. Indonesia.

Pelczar J., Jr. Michael, E.C.S.Chan, 1986. Dasar-Dasar Mikrobiologi.Edisi 1. Penerjemah Ratna Siri Hadioetomo, dkk. Penerbit Universitas Indonesia (UI-Press). Jakarta.

Pelczar, M. dan Chan. 1988.Dasar-Dasar Mikrobiologi (Jilid 1). UI Press. Jakarta.

Rachman, I.S. 2011. Uji Aktivitas Ekstrak Biji Pepaya Terhadap Staphyloccocus aureus, Akademi Farmasi Putra Malang, Indonesia. 